\title{
Linking cyclic stress and cyclic strain based methods for assessment of cyclic liquefaction triggering in sands
}

\author{
J. A. SCHNEIDER* and R. E. S. MOSS†
}

\begin{abstract}
Contradictory conclusions may arise when assessing liquefaction resistance of sands based on penetration tests and shear wave velocity. To provide a more unified analysis framework, this letter couples cyclic stress and cyclic strain based analysis of liquefaction triggering using site-specific correlations between penetration resistance and small strain shear modulus from shear wave velocity using the seismic cone tests. Cyclic strain theory provides a robust lower limit to liquefaction resistance, and analyses indicate that relatively high ratios of small strain stiffness to penetration resistance lead to high liquefaction resistance at relatively low cyclic stress ratios. The increased resistance to liquefaction from relatively high stiffness values is suspected to break down at higher cyclic stress ratios, where liquefaction resistance is controlled by the potential for soil to dilate, which correlates well with effective stress normalised cone tip resistance. The analysis framework is in general agreement with laboratory and field data that are predominantly Holocene in origin; however further validation by a comprehensive lab testing programme is warranted.
\end{abstract}

KEYWORDS: in situ testing; liquefaction; sands

ICE Publishing: all rights reserved

\section{INTRODUCTION}

Analysis of soil liquefaction resistance based on in situ tests can result in contradictory conclusions when different measurements are used, particularly high-strain measurements from penetration tests and low-strain measurements from shear wave velocity. Liquefaction resistance is controlled by two distinctly different mechanisms - where high soil stiffness initially resists the development of shear strains and where high dilation angles minimise the consequences of liquefaction at higher strain levels. This letter sets out a framework in which these two aspects of liquefaction resistance are addressed separately and correlations between penetration resistance and shear modulus are used to link the two mechanisms within conventional design charts.

Cyclic strain theory (Dobry et al., 1982) provides a robust lower limit for liquefaction resistance: if a threshold shear strain is not exceeded, no shear-induced pore pressures will develop and there will be no reduction in stiffness or strength due to cyclic loading. This letter explores the following hypotheses.

(a) Cyclic strain theory, with resistance based on $G_{0}$ (smallstrain shear modulus) and a threshold shear strain, provides a lower limit for liquefaction resistance.

(b) The influence of dilation at higher strain levels limits the consequences of liquefaction and better correlates to penetration resistance, specifically cone penetration test $(\mathrm{CPT})$ cone tip resistance $\left(q_{\mathrm{c}}\right)$ for soils of the same high-stress compressibility.

Manuscript received 10 March 2011; first decision 17 April 2011; accepted 19 May 2011.

Published online at www.geotechniqueletters.com on 16 June 2011.

${ }^{*}$ Civil \& Environmental Engineering, University of Wisconsin Madison, WI, USA

$\uparrow$ Civil \& Environmental Engineering, Cal Poly State University San Luis Obispo, CA, USA (c) Correlations between $G_{0}$ and $q_{\mathrm{c}}$ exist that can link cyclic stress and cyclic strain based approaches, but these correlations are not unique and should be updated with results from seismic cone tests.

(d) Coupled cyclic stress and cyclic strain based assessment of liquefaction resistance indicates that soils with high relative ratios of $G_{0} / q_{\mathrm{c}}$ (i.e. $K_{\mathrm{G}}$ (see the next section)) have a liquefaction resistance at low levels of cyclic loading that is greater than typical liquefaction resistance correlations based on the $q_{\mathrm{c}}$ of Holocene sands.

By incorporating relationships between $G_{0}$ and $q_{\mathrm{c}}$, increases in stiffness due to factors such as soil ageing or cementation become an implicit component of a liquefaction analysis.

\section{CORRELATIONS BETWEEN CONE TIP RESISTANCE AND SHEAR WAVE VELOCITY}

Correlations between $G_{0}$ and $q_{\mathrm{c}}$ exist, but they are not unique (e.g. Rix \& Stokoe, 1991). $G_{0}$ is a small-strain property controlled by the relative number of particle contacts, the characteristics of those particle contacts and the effective stress state (e.g. Santamarina et al., 2001), whereas $q_{\mathrm{c}}$ is a large-strain property that is controlled by a larger strain shear stiffness, high-stress crushability of the soil, dilation angle and the horizontal effective stress state (e.g. Salgado et al., 1997). Therefore, measurement of in situ $G_{0}$ and $q_{\mathrm{c}}$ through the use of a seismic cone test can be used to reduce the uncertainty in correlations between strength and stiffness, which is particularly useful for aged and cemented sands. Since the ratio of $G_{0} / q_{\mathrm{c}}$ is influenced by relative density and effective stress as well as age and cementation (e.g. Eslaamizaad \& Robertson, 1996; Fahey et al., 2003; Schnaid et al., 2004), $G_{0} / q_{\text {c }}$ cannot be used alone to reduce uncertainty in liquefaction-triggering correlations. The empirical parameter $K_{\mathrm{G}}$, as defined in equation (1) (after Rix \& Stokoe (1991)), will be used to account for sand relative density and effective stress level on the correlation between $G_{0}$ and $q_{\mathrm{c}}$ : 


$$
K_{G}=\frac{G_{0} / q_{\mathrm{c}}}{\left[\left(q_{\mathrm{c}} / p_{\mathrm{ref}}\right) /\left(\sigma^{\prime}{ }_{\mathrm{v} 0} / p_{\mathrm{ref}}\right)^{0 \cdot 5}\right]^{-m}}=\frac{G_{0} / q_{\mathrm{c}}}{q_{\mathrm{clN}}{ }^{-m}}
$$

where $\sigma_{\mathrm{v} 0}^{\prime}$ is the initial in situ vertical effective stress, $p_{\text {ref }}$ is a reference stress equal to $100 \mathrm{kPa}, m$ is an empirical exponent typically taken as 0.75 (e.g. Rix \& Stokoe, 1991; Schneider et al., 2004) and $q_{\mathrm{clN}}$ is the stress normalised cone tip resistance using a median sand overburden stress exponent of 0.5 (Moss et al., 2006b).

Seismic cone data from eight studies are summarised in Table 1 and Fig. 1. Aged, cemented and calcareous sands tend to have values of $K_{\mathrm{G}}$ between 330 and 1100 , while Holocene sands tend to have a $K_{\mathrm{G}}$ of $110-330$, with a median value of 215 . These ranges are in good agreement with previous recommendations of Rix \& Stokoe (1991) and Schnaid et al. (2004). The following section develops a lower limit of liquefaction resistance in sandy soils based on cyclic strain theory.

\section{CYCLIC STRAIN BASED ASSESSMENT OF LIQUEFACTION TRIGGERING}

The lower limits of liquefaction resistance can be defined where induced cyclic strains fall below the elastic threshold shear strain. An elastic threshold strain would be independent of the number of cycles of loading, therefore the number of loading cycles is not explicitly accounted for in this study. Data reported by Dobry et al. (1982) and Stokoe et al. (2008) support an elastic threshold strain of $1 \times 10^{-4}$ that is independent of the number of cycles of loading typical of earthquakes ( $<30$ cycles). The small-strain shear modulus $\left(G_{0}\right)$ normalised by the initial in situ vertical effective stress $\left(\sigma_{\mathrm{v} 0}^{\prime}\right)$ can be used to calculate a threshold shear strain $\left(\gamma_{\mathrm{th}}\right)$ based on the cyclic stress ratio $\left(\mathrm{CSR}=\tau / \sigma_{\mathrm{v} 0}^{\prime}\right)$ :

$$
\gamma_{\mathrm{th}}=\frac{\tau_{\mathrm{th}}}{G_{0}}=\frac{\tau_{\mathrm{th}} / \sigma_{\mathrm{v} 0}^{\prime}}{G_{0} / \sigma_{\mathrm{v} 0}^{\prime}}=\frac{\mathrm{CSR}}{G_{0} / \sigma_{\mathrm{v} 0}^{\prime}}
$$

Figure 2(a) compares field case histories (Andrus and Stokoe, 2000) with shear wave velocity data where

\begin{tabular}{|c|c|c|c|c|c|c|c|c|}
\hline Sand & $\underset{K_{\mathrm{G}}{ }^{*}}{\text { Median }}$ & $\begin{array}{l}K_{\mathrm{G}} \\
\mathrm{CoV}\end{array}$ & Mineralogy & $\begin{array}{c}\text { Single } \\
\text { site }\end{array}$ & Aged/cemented & Lab/field & Fig. & Reference \\
\hline Italian & 212 & $0 \cdot 14$ & Siliceous & No & No & Field & $1(\mathrm{a})$ & $\begin{array}{l}\text { Baldi et al. } \\
\text { (1989) }\end{array}$ \\
\hline $\begin{array}{l}\text { Washed mor- } \\
\text { tar }\end{array}$ & 361 & $0 \cdot 13$ & Siliceous & Yes & No & Lab & 1(a) & $\begin{array}{l}\text { Rix \& Stokoe } \\
\text { (1991) }\end{array}$ \\
\hline Heber Road & 181 & $0 \cdot 17$ & Siliceous & Yes & No & Lab & $1(a)$ & $\begin{array}{l}\text { Rix \& Stokoe } \\
\text { (1991) }\end{array}$ \\
\hline $\begin{array}{l}\text { Mississippi } \\
\text { River }\end{array}$ & 221 & $0 \cdot 24$ & Siliceous & No & No & Field & $1(a)$ & $\begin{array}{l}\text { Schneider et al. } \\
\text { (2004) }\end{array}$ \\
\hline Shenton Park & 513 & $0 \cdot 20$ & Siliceous & Yes & Yes & Field & $1(\mathrm{~b})$ & $\begin{array}{l}\text { Schneider et al. } \\
(2008)\end{array}$ \\
\hline Ledge Point & 491 & $0 \cdot 22$ & Calcareous & Yes & No & Field & $1(b)$ & $\begin{array}{l}\text { Schneider \& } \\
\text { Lehane (2010) }\end{array}$ \\
\hline Quiou & 303 & $0 \cdot 18$ & Calcareous & Yes & No & Lab & $1(\mathrm{~b})$ & $\begin{array}{l}\text { Fioravante et } \\
\text { al. (1998) }\end{array}$ \\
\hline Perth aged & 518 & $0 \cdot 49$ & $\begin{array}{l}\text { Siliceous / } \\
\text { Calcareous }\end{array}$ & No & Yes & Field & $1(c)$ & $\begin{array}{l}\text { Fahey et al. } \\
(2003)\end{array}$ \\
\hline $\begin{array}{l}\text { Holocene } \\
\text { liquefaction }\end{array}$ & 181 & $0 \cdot 49$ & Siliceous & No & No & Field & $1(\mathrm{~d})$ & Roy (2008) \\
\hline $\begin{array}{l}\text { Holocene no } \\
\text { liquefaction }\end{array}$ & 184 & $0 \cdot 56$ & Siliceous & No & No & Field & $1(\mathrm{~d})$ & Roy (2008) \\
\hline $\begin{array}{l}\text { Pleistocene } \\
\text { liquefaction }\end{array}$ & 213 & 0.43 & Siliceous & No & Yes & Field & $1(\mathrm{e})$ & Roy (2008) \\
\hline $\begin{array}{l}\text { Pleistocene no } \\
\text { liquefaction }\end{array}$ & 368 & 0.67 & Siliceous & No & Yes & Field & 1(e) & Roy (2008) \\
\hline $\begin{array}{l}\text { Laboratory } \\
\text { Holocene }\end{array}$ & 210 & $0 \cdot 20$ & Siliceous & No & Yes/No & Lab & $1(\mathbf{f})$ & Roy (2008) \\
\hline $\begin{array}{l}\text { Laboratory } \\
\text { Pleistocene }\end{array}$ & 408 & $0 \cdot 25$ & Siliceous & No & Yes/No & Lab & $1(\mathbf{f})$ & Roy (2008) \\
\hline $\begin{array}{l}\text { All siliceous } \\
\text { Holocene } \\
\text { sands in this } \\
\text { table }\end{array}$ & 214 & $0 \cdot 39$ & Siliceous & No & No & Both & - & - \\
\hline
\end{tabular}

Table 1. Summary of data used in evaluation of correlations between CPT cone tip resistance and small-strain shear modulus

*For exponent $m=0 \cdot 75$ 
(a)

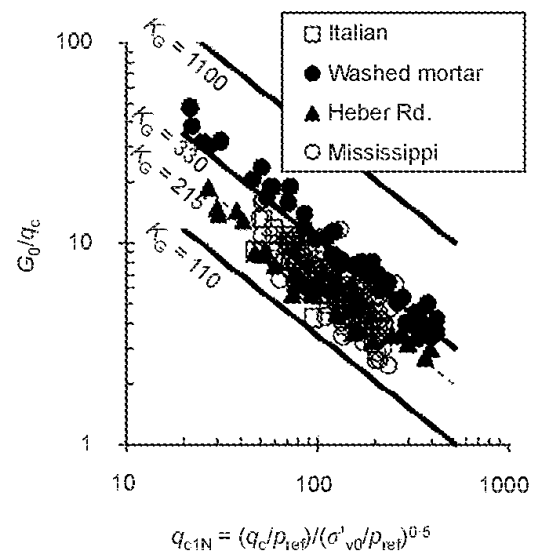

(b)

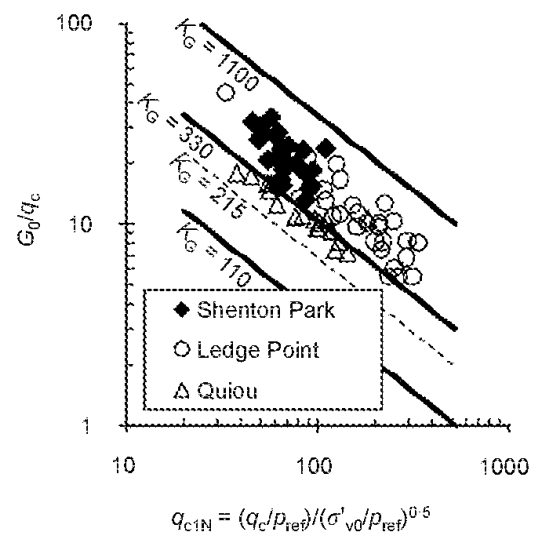

(c)

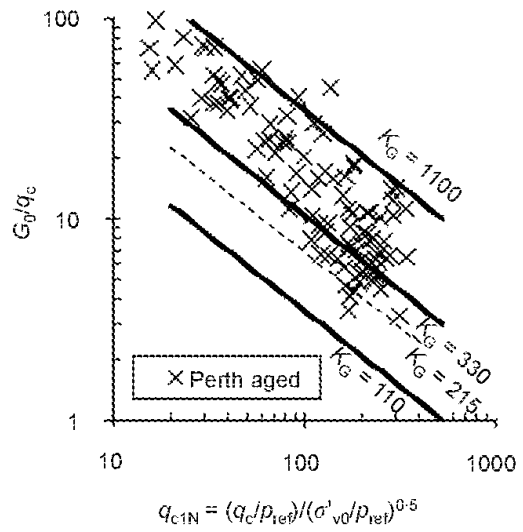

(d)

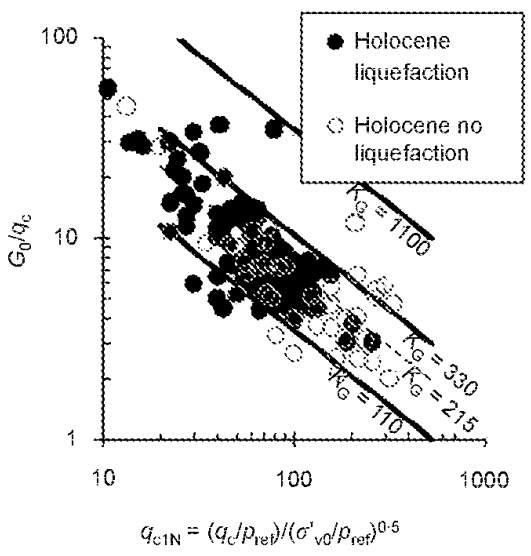

(e)

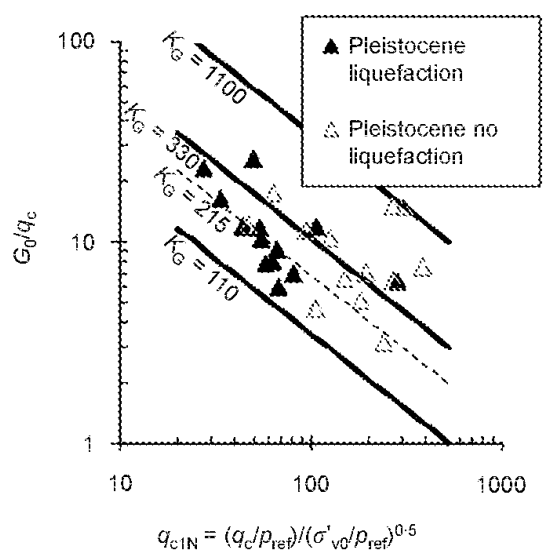

(f)

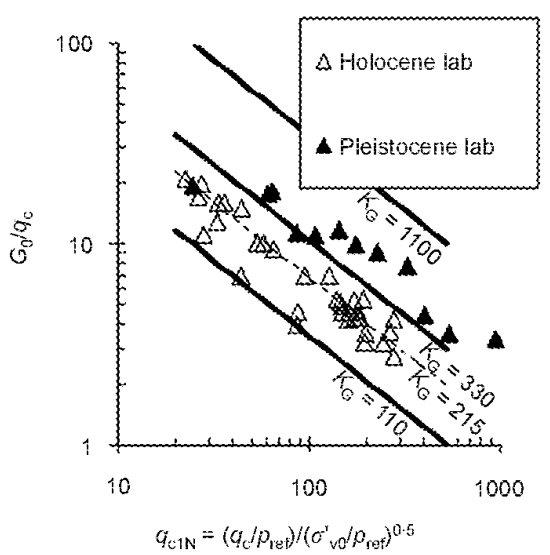

Fig. 1. Correlations between normalised cone tip resistance and small-strain shear modulus measured in seismic cone tests for various sand deposits (see Table 1 for details)

liquefaction was observed during earthquakes to a threshold shear strain of $1 \times 10^{-4}$. Figure $2(\mathrm{~b})$ presents case histories where liquefaction was not observed, compared with a higher equivalent threshold shear strain of $4 \times 10^{-4}$. Normalised average cyclic loading from field case histories $\left(\mathrm{CSR}=\tau_{\mathrm{avg}} / \sigma_{\mathrm{v} 0}^{\prime}\right)$ tends to increase with $\mathrm{G}_{0} / \sigma_{\mathrm{v} 0}^{\prime}$. For case histories where soils have liquefied, the $\mathrm{CSR}$ is the maximum cyclic resistance ratio $(\mathrm{CRR}=$ $\left.\tau_{\mathrm{avg}} / \sigma_{\mathrm{v} 0}^{\prime}\right)$ that the soil could have experienced during the earthquake. For case histories where soils have not liquefied, the CSR is the minimum CRR that the soil could have experienced during the earthquake. A threshold shear strain of $1 \times 10^{-4}$ provides a minimum level of liquefaction resistance for the database of case histories with a typically initial vertical effective stress level of $50 \mathrm{kPa}$. Layers that were subjected to higher cyclic stresses but did not result in observations of liquefaction likely had the consequences of liquefaction minimised due to dilation at higher shear strains.

CPT case histories where $G_{0}$ was not explicitly measured can be evaluated within the same framework if a correlation between $G_{0}$ and $q_{\mathrm{c}}$ is assumed. The database from Moss $e t$ al. 

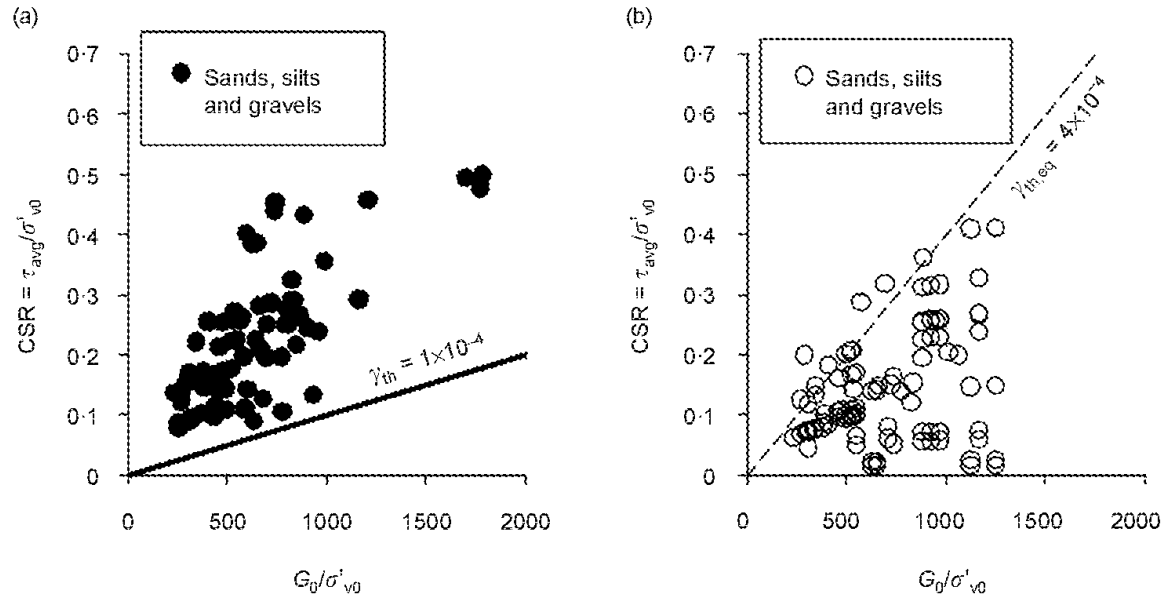

Fig. 2. Field database of liquefaction case histories in sandy soils (Andrus \& Stokoe, 2000) with shear wave velocity $\left(G_{0}=\rho V_{s}^{2}\right.$ ) compared with threshold strain levels: (a) liquefaction cases; (b) non-liquefaction cases

(2006a) is analysed in Fig. 3 using equation (1) with $m=0.75$ and $K_{\mathrm{G}}=215$ (median of Holocene siliceous subset database). A similar minimum liquefaction resistance related to a threshold shear strain of $1 \times 10^{-4}$ is observed for the CPT database when the median correlation between $G_{0}$ and $q_{\mathrm{c}}$ is used.

\section{COMBINING CYCLIC STRAIN WITH CYCLIC STRESS BASED ASSESSMENT OF LIQUEFACTION TRIGGERING}

The minimum value of liquefaction resistance, represented by the threshold strain, can be equated to the CRR using the ratio of $\mathrm{G}_{0} / \sigma_{\mathrm{v} 0}^{\prime}$, as illustrated in equation (3a) (cf. equation (2)). Using the correlation between $G_{0}$ and $q_{\mathrm{c}}$ (equation (1)), the minimum liquefaction resistance can be expressed as a function of cone tip resistance and initial vertical effective stress (equation (3b)).

$$
\begin{aligned}
& \mathrm{CRR} \geq \frac{\tau_{\mathrm{th}}}{\sigma_{\mathrm{v} 0}^{\prime}} \geq \frac{G_{0} \gamma_{\mathrm{th}}}{\sigma_{\mathrm{v} 0}^{\prime}} \\
& \mathrm{CRR} \geq \frac{\tau_{\text {th }}}{\sigma_{\mathrm{v} 0}^{\prime}} \geq \frac{K_{\mathrm{G}} q_{\mathrm{clN}}{ }^{-0.75} q_{\mathrm{c}} \gamma_{\mathrm{th}}}{\sigma_{\mathrm{v} 0}^{\prime}}
\end{aligned}
$$

Figure 4 compares the cyclic resistance from laboratory tests on Holocene and Pleistocene samples collected using freezing techniques (Roy, 2008) with cyclic resistance

(a)

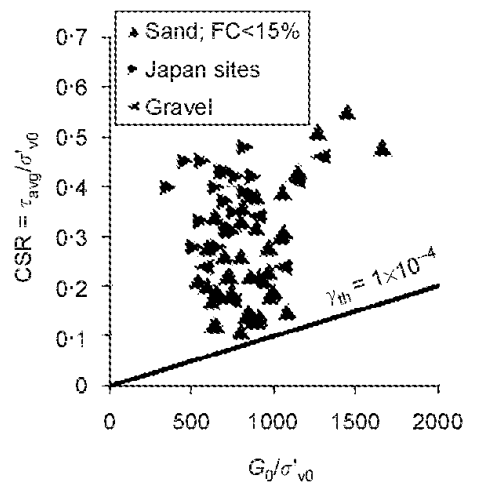

calculated using equation (3b). A threshold strain level of $1 \times 10^{-4}$ and effective vertical stress of $50 \mathrm{kPa}$ is used in equation ( $3 \mathrm{~b}$ ) for consistency with Figs 2 and 3 and databases of liquefaction case histories. The effects of stress level on threshold strain have been discussed in the literature (e.g. Dobry et al., 1982; Santamarina \& Aloufi, 1995; Santamarina et al., 2001); the influence of stress level on equation ( $3 b)$ requires further study. Use of the Roy (2008) dataset in Fig. 4 allows exploration of the following two issues.

(a) Since the data are from laboratory tests, there is less ambiguity as to the stress ratio that causes liquefaction when compared to field case histories.

(b) Pleistocene soils are not typically included in liquefaction case history databases and are expected to have higher values of liquefaction resistance (e.g. Arango \& Migues, 1996; Hayati \& Andrus, 2009; Leon et al., 2006; Moss et al., 2008; Pyke, 2003; Roy, 2008; Seed, 1979). Incorporation of soil age into design method formulations generally does not significantly reduce uncertainty in the analysis for two reasons. First, the actual age of a soil deposit is rarely measured in a geotechnical site investigation. Second, in areas that are subject to high seismic activity, liquefiable soils tend to re-liquefy in historical seismic events (Youd 1984). In relation to the second point, recurring historic liquefaction events may destroy the

(b)

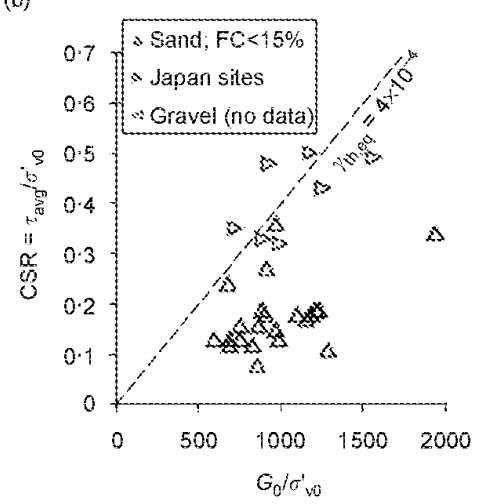

Fig. 3. Field database of liquefaction case histories in sandy soils (Moss et al., 2006a) with shear modulus estimated from cone tip resistance $\left(G_{0} / q_{c}=215 q_{\mathrm{c} 1 \mathrm{~N}}{ }^{-0.75}\right)$ compared with threshold strain levels: (a) liquefaction cases in sands and gravels; (b) nonliquefaction cases in sands and gravels 
(a)
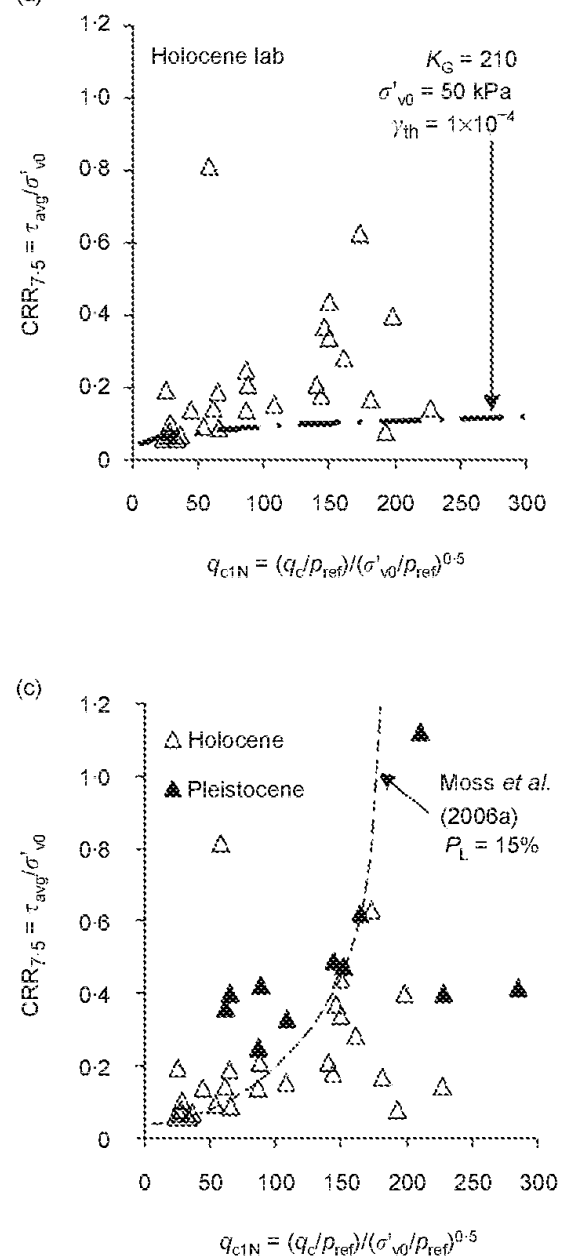

(b)

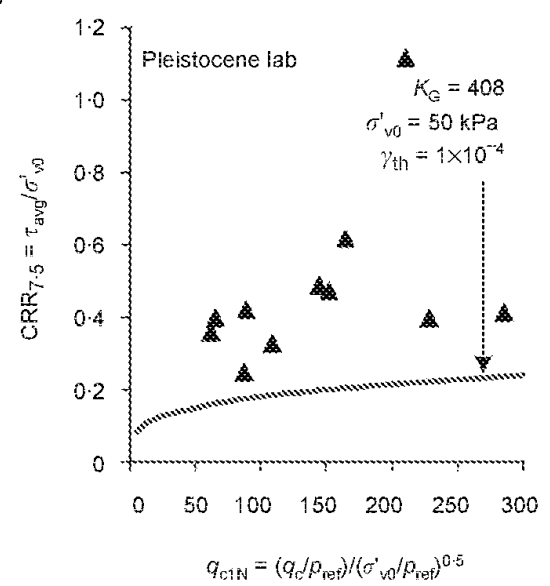

(d)

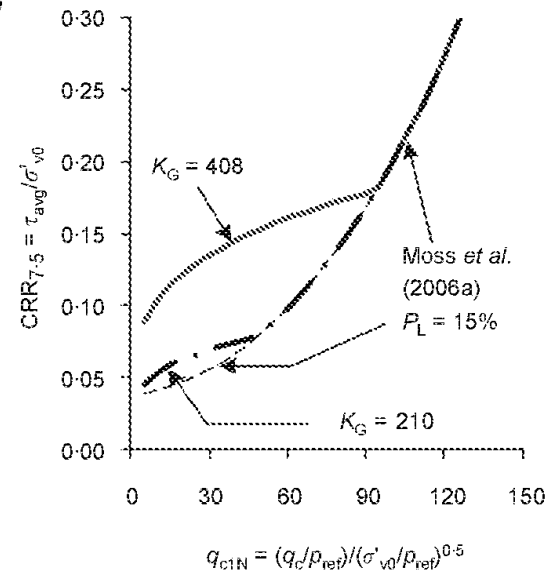

Fig. 4. Combination of cyclic stress and cyclic strain based analysis of liquefaction triggering for $\gamma_{\mathrm{th}}=1 \times 10^{-4}$ and $\sigma_{\mathrm{v} 0}^{\prime}=50 \mathrm{kPa}$. (a) Cyclic strain assessment compared with Holocene lab data with effective confining stress $\sigma^{\prime}$ c0 $<250 \mathrm{kPa}$ from Roy (2008). (b) Cyclic strain assessment compared with Pleistocene lab data with $\sigma_{\mathrm{c} 0}^{\prime}<250 \mathrm{kPa}$ from Roy (2008). (c) Holocene and Pleistocene lab data with $\sigma_{\mathrm{c} 0}^{\prime}<250 \mathrm{kPa}$ from Roy (2008) compared with cyclic stress boundary for Holocene sands (Moss et al., 2006a). (d) Conceptual combined analysis using cyclic strain theory in Fig. 4(a) and 4(b) with cyclic stress theory from Fig. 4(c)

structure and/or bonding effects often induced by ageing that increase liquefaction resistance. An aged soil that had previously liquefied could then have similar engineering properties (strength and stiffness) as a young soil, and therefore have similar resistance to liquefaction during a seismic event.

Analysis of Roy's (2008) data uses a sample median $K_{\mathrm{G}}$ value of 210 for Holocene sands in Fig. 4(a) and 408 for the Pleistocene sands in Fig. 4(b) (Table 1). The Pleistocene sands tend to show higher liquefaction resistance than Holocene sands for $q_{\mathrm{clN}}$ less than about 150 , where dilation is considered to have less influence on liquefaction resistance. For a number of cases with $q_{\mathrm{c} 1 \mathrm{~N}}$ greater than about 150 , the liquefaction resistance of Holocene sands approaches that of Pleistocene sands with the same cone tip resistance. These data tend to fall along the cyclic stress based $\left(P_{\mathrm{L}}=15 \%\right)$ liquefaction resistance curve of Moss et al. (2006a). For data falling along this curve, the consequences of liquefaction are limited by dilation at larger strain levels and any increase in resistance is minimised when ageing effects have been broken down at larger strains.

Figure 4(d) is a conceptual diagram that combines cyclic strain based liquefaction resistance with cyclic stress based curves. At low values of normalised cone tip resistance, stiffness controls liquefaction resistance and Pleistocene soils have a higher liquefaction resistance for the same cone tip resistance, as indicated by $K_{\mathrm{G}}$. For these curves, the increase in liquefaction resistance is approximately a factor of 2, in agreement with the previous studies of Arango and Migues (1996) and Moss et al. (2008). At higher values of normalised cone tip resistance, the consequences of liquefaction are limited by dilation, and correlations to $q_{\mathrm{c} 1 \mathrm{~N}}$ for Holocene soils may be applicable to both Holocene and Pleistocene deposits. When combining these two methods in one plot, the strain based approach generally controls the behaviour of aged soils below $q_{\mathrm{clN}}$ of about 100 and the stress based approach above $q_{\mathrm{c} 1 \mathrm{~N}}=100$. There are some Pleistocene points that follow the trends of the cyclic strain lower limit in Fig. 4b; these need further investigation through controlled laboratory studies.

\section{CONCLUSIONS}

Cyclic strain theory produces a lower limit for liquefaction resistance through the threshold strain. Application of correlations between $G_{0}$ and $q_{\mathrm{c}}$ link cyclic stress and cyclic strain based assessment of liquefaction analyses within 
traditional CRR versus $q_{\mathrm{clN}}$ charts. For soils of low normalised cone tip resistance in which dilation does not significantly increase liquefaction resistance, cyclic strain based assessment of liquefaction resistance matches well with cyclic stress based liquefaction limits in Holocene soils. For Pleistocene soils with higher ratios of stiffness to strength (i.e. high $K_{\mathrm{G}}$ ), the lower limits of liquefaction resistance based on cyclic strain theory result in CRR values that are approximately twice those of Holocene soils for a $q_{\mathrm{c} 1 \mathrm{~N}}$ less than about 100 . These higher levels of liquefaction resistance are consistent with previous observations and provide a conceptual framework for understanding this behaviour. A comprehensive programme of laboratory testing of uncemented, cemented and aged soils, with measurements of liquefaction strength and smallstrain shear modulus, would help to extend the analysis discussed here.

\section{REFERENCES}

Andrus, R. D. \& Stokoe, K. H. I. I. (2000). Liquefaction resistance of soils from shear-wave velocity. $J$. Geotech. Geoenviron. Engng 126, No. 11, 1015-1025.

Arango, I. \& Migues, R. E. (1996). Investigation on the seismic liquefaction of old sand deposits. Bechtel, San Francisco, CA, NSF research report, grant no. CMS-9416169.

Baldi, G., Bellotti, R., Ghionna, N., Jamiolkowski, M. \& LoPresti, D. C. F. (1989). Modulus of sands from CPTs and DMTs. Proc. 12th Int. Conf. on Soil Mech. \& Foundation Eng., Rio de Janeiro, 1, 165-170.

Dobry, R., Ladd, R. S., Yokel, F. Y., Chung, R. M. \& Powell, D. (1982). Prediction of pore water pressure buildup and liquefaction of sands during earthquake by the cyclic strain method. National Bureau of Standards, Gaithersburg, MD, NBS Building Science Series 138.

Eslaamizaad, S. \& Robertson, P. K. (1996). Seismic cone penetration test to identify cemented sands. Proc. 49 th Canadian Geotech. Conf., St John's, Newfoundland, 1, 352-360.

Fahey, M., Lehane, B. M. \& Stewart, D. P. (2003). Soil stiffness for shallow foundation design in the Perth CBD. Austral. Geomech. J. 38, No. 3, 61-89.

Fioravante, V., Jamiolkowski, M., Ghionna, V. N. \& Pedroni, S. (1998). Stiffness of carbonatic Quiou sand from CPT. Proc. Geotechnical Site Characterization ISC'98, Atlanta, GA, 2, 1039-1049.

Hayati, H. \& Andrus, R. D. (2009). Updated liquefaction resistance correction factors for aged sands. J. Geotech. Geoenviron. Engng 135, No. 11, 1683-1692.

Leon, E., Gassman, S. L. \& Talwani, P. (2006). Accounting for soil aging when assessing liquefaction potential. J. Geotech. Geoenviron. Engng 132, No. 3, 363-377.

Moss, R. E. S., Seed, R. B., Kayen, R. E., et al. (2006a). CPTbased probabilistic and deterministic assessment of in situ seismic soil liquefaction potential. J. Geotech. Geoenviron. Engng 132. No. 8, 1032-1051.

Moss, R. E. S., Seed, R. B. \& Olsen, R. S. (2006b). Normalizing the CPT for overburden stress. J. Geotech. Geoenviron. Engng 132, No. 3, 378-387.

Moss, R. E. S., Thornhill, D. M., Nelson, A. I. \& Levulett, D. A (2008). Influence of aging on liquefaction potential: preliminary results. Geotechnical Earthquake Engineering and Soil Dynamics $I V, A S C E$ GSP 181, 1-10.

Pyke, R. (2003). Discussion of 'Liquefaction resistance of soils: Summary report from the 1996 NCEER and 1998 NCEER/ NSF workshops on liquefaction resistance of soils' by Youd et al. J. Geotech. Geoenviron. Engng, 129, No. 3, 283-284.

Rix, G. J. \& Stokoe K. H. II. (1991). Correlation of initial tangent modulus and cone penetration resistance. In Calibration chamber testing. New York: Elsevier, pp. 351-361.

Roy, D. (2008). Coupled use of cone tip resistance and small strain shear modulus to assess liquefaction potential. J. Geotech. Geoenviron. Engng, 134, No. 4, 519-530.

Salgado, R., Mitchell, J. K. \& Jamiolkowski, M. (1997). Cavity expansion and penetration resistance in sand. $J$. Geotech. Geoenviron. Engng, 123, No. 4, 344-354.

Santamarina, J. C. \& Aloufi, M. (1995). Small strain stiffness: a micromechanical experimental study. In Pre-failure deformation characteristics of geomaterials, Rotterdam: Balkema, pp. 451-458.

Santamarina, J. C., Klein, K. A. \& Fam, M. A. (2001). Soils and waves. New York: Wiley.

Schnaid, F., Lehane, B. M. \& Fahey, M. (2004). In situ characterization of unusual geomaterials. Proc. 2nd Int. Conf. on Geotech. and Geophysical Site Characterization, Porto, Portugal, 49-74

Schneider, J. A. \& Lehane, B. M. (2010). Evaluation of cone penetration testing from a calcareous sand dune. Proc. Int. Conf. on Cone Penetration Testing, CPT'10, Huntington Beach, $C A$, Paper 2-28.

Schneider, J. A. McGillivray, A. V. \& Mayne, P. W. (2004). Evaluation of SCPTU intra-correlations at sand sites in the lower Mississippi River Valley, USA. Proc. 2nd Int Conf. on Geotech. and Geophysical Site Characterization, Porto, Portugal, 1, 1003-1010.

Schneider, J. A., Fahey, M. \& Lehane, B. M. (2008). Characterisation of an unsaturated sand deposit by in situ testing. Proc. 3rd Int. Conf. on Site Characterization, ISC'3, Taipei, Taiwan, CD-ROM, 633-638.

Seed, H. B. (1979). Soil liquefaction and cyclic mobility for level ground during earthquakes. J. Geotech. Engng ASCE, 105, No. $2,201-255$.

Stokoe II, K. H., Menq, F.-Y., Wood, S. L., et al. (2008). Experience with nees@UTexas large-scale mobile shakers in earthquake engineering studies. Proc. 3rd Int. Conf. on Geotech. and Geophysical Site Characterization, Taipei, Taiwan, CD-ROM, 1365-1371.

Youd T. L. (1984). Recurrence of liquefaction at the same site. Proc. 8th World Conf. on Earthquake Engng, San Francisco, CA, III, 231-238.

\section{WHAT DO YOU THINK?}

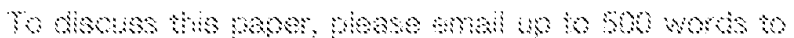

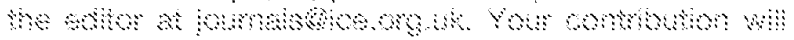

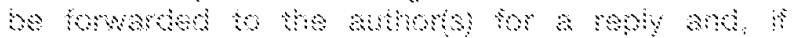

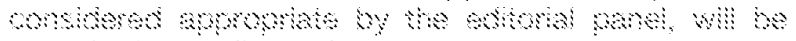

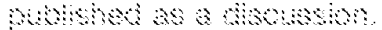

